\title{
The immune system in the control of microbiota homeostasis
}

\author{
Giuseppe Penna*, Maria Rescigno \\ From XXI Congress of the Italian Society of Neonatology \\ Palermo, Italy. 24-26 September 2015
}

\section{Background}

In the intestine, dendritic cells (DCs) are found in the lamina propria (LP) of the villi, in the mesenteric lymph nodes (MLN), lymphoid aggregates and Peyer's Patches (PP). Probably the most represented antigen presenting cells in the gut are those found in the LP as they definitely outnumber the number of DCs found in the MLN or PP. In the mouse, these mononuclear phagocytes can be divided into subgroups depending on the expression of CX3CR1 (the receptor of fraktalkine) and CD103 (E iIntegrin). CD103+ conventional DCs become tolerogenic in the gut, via their interaction with the local microenvironment and in particular with epithelial cells. Indeed, at steady state, ECs (Epithelial cells)condition anti-inflammatory DCs through the constitutive release of TSLP, TGF-b and retinoic acid (RA). EC-conditioned DCs even though phenotypically activated by bacteria polarize $\mathrm{T}$ cells towards a mucosal non-inflammatory $\mathrm{T}$ helper-2 phenotype or $\mathrm{T}$ regulatory cells. CX3CR $1+$ cells are instead apt at bacteria and food antigen uptake that they then transfer to CD103+ DCs via a gap junction-dependent mechanism. The interaction allows the establishment of tolerance to luminal antigens [1].

The microbiota can influence the cross-talk between immune cells and the mucosal microenvironment [2]. Thus the interplay between nutrition, microbiota and immune cells is decisive for the subsequent health of the infant. The rapid expansion of commercially available fermented food products raises important safety issues particularly when infant food is concerned. In many cases, the activity of the microorganisms used for fermentation as well as what will be the immunological outcome of fermented food intake is not known.

\footnotetext{
* Correspondence: giuseppe.penna@ieo.eu Department of Experimental Oncology, European Institute of Oncology, and Department of health Sciences, Universita' di Milano, Via Adamello 16, Milan,
} Italy

\section{Materials and methods}

We used established in vivo, in vitro and ex vivo models of infection/inflammation to study the immunomodulatory effects of fermented products of Lactobacillus paracasei CBA L74.

\section{Results}

We found in vitro and ex-vivo that fermented products of Lactobacillus paracasei CBA L74 act via the inhibition of proinflammatory cytokine release leaving antiinflammatory cytokines either unaffected or even increased in response to Salmonella typhimurium. These activities are not dependent on the inactivated bacteria but to metabolic products released during the fermentation process. Indeed CBA L74 fermented products (both culture medium and fermented milk) could protect against colitis and against an enteric pathogen infection (Salmonella typhimurium). Hence we found that fermented products can act via the inhibition of mune cell inflammation and can protect the host

\section{Conclusions}

These results open new perspectives in infant nutrition and suggest that L. paracasei CBA L74 fermented formula can provide immune benefits to an immature infant immune system.

\section{Published: 24 September 2015}

\section{References}

Mazzini E, Massimiliano L, Penna G, Rescigno M: "Oral tolerance can be established via gap junction transfer of fed antigens from CX3CR1(+) macrophages to CD103(+) dendritic cells.". Immunity 2014, 40(2):248-261.

2. Clemente J C, Ursell L K, Parfrey L W, Knight R: "The impact of the gut microbiota on human health: an integrative view.". Cell 2012, 148(6):1258-1270.

3. Zagato E, Mileti E, Massimiliano L, Fasano F, Budelli A, Penna G, Rescigno M: "Lactobacillus paracasei CBA L74 metabolic products and fermented 
milk for infant formula have anti-inflammatory activity on dendritic cells in vitro and protective effects against colitis and an enteric pathogen in vivo.". PLoS One 2014, 9(2):e87615.

doi:10.1186/1824-7288-41-S1-A29

Cite this article as: Penna and Rescigno: The immune system in the control of microbiota homeostasis. Italian Journal of Pediatrics 2015 41(Suppl 1):A29.

Submit your next manuscript to BioMed Central and take full advantage of:

- Convenient online submission

- Thorough peer review

- No space constraints or color figure charges

- Immediate publication on acceptance

- Inclusion in PubMed, CAS, Scopus and Google Scholar

- Research which is freely available for redistribution

Submit your manuscript at www.biomedcentral.com/submit 